\title{
MNL に基づく出発時刻選択行動モデルを用いた通勤鉄道利用者の列車待ち時間に対する 意識限界に関する実証的分析* \\ Valuation of Perception Threshold for Waiting Time at Railway Station by the Departure Time Choice Model Based on the MNL model*
}

\author{
加藤浩德*，家田 仁***，小野田惠一**** \\ By Hironori KATO ${ }^{* *}$, Hitoshi IEDA ${ }^{* *}$, Keiichi ONODA ${ }^{* * *}$
}

\section{1. はじめに}

一般に，交通選択行動においては，代替案となる交通 機関や経路のサービス水準の差が選択に大きく影響を与 えると考えられる. だが，サービス水準の差がごく僅か な場合には，利用者にはその差が十分知覚されない，あ るいはできない可能性がある．したがって，交通行動分 析を行う上では，人はどの程度のサービス水準の差なら ば，それを有効な差であると知覚し，異なる選択行動を とるようになるかという意識の限界を知る必要があると 考えられる.

しかし，利用者がサービス水準の差を意識しているか どうかを直接尋ねることは実際には困難である. そこで 本研究では，サービス水準のうち，特に時間を取り上げ, 通勤者本人から時刻制約に関する情報を直接尋ねると同 時に，その利用者の時刻選択行動を観測することにより， 各通勤者のスケジュール変動の費用を推定し，それをも とに列車待ち時間の意識限界を推定することを目的とす る.

ところで，交通行動に関するサービス水準の意識限界 に関連する研究は，既にいくつか行われている，まず， Krishnan'1，2 肢選択ロジットモデルにおいて，選択肢 間の効用差が小さい場合にはランダムな選択が行われる との仮説の下，最小知覚差を考慮した MPD モデルを提 唱した. これを基に筆者ら ${ }^{2}$ は多肢選択モデルに拡張の 上，都市鉄道の経路選択行動を分析し，人間の最小知覚 差が所要時間に換算して約 76 秒であることを示した. また，小野ら ${ }^{31}$ は，幹線旅客鉄道における所要時間短縮 に関して，意識データを用いて，その効果の評価方法を 検討し，2〜4 時間の総所要時間に対し，10 分程度が短 縮効果認識の限界であり，また短縮効果は時間の大台を 切るなどのPR の影響が少なくないことなどを示した.

* キーワーズ: 交通行動分析

** 正会員, 博(工), 東京大学大学院工学系研究科社会基般工学 専攻 専任講師

（テ113-8656 東京都文京区本郷7丁目 3 番地 1 号, Tel: 03-5841-7451, Fax: 03-5841-8506)

*** 正会員, 工博, 東京大学大学院工学系研究科社会基盤工学 専攻 教授

****学生会員, 東京大学大学院工学系研究科社会基盤工学専攻 修士課程
本研究のアプローチに最も近いと考えられるのは，家 田ら ${ }^{4)}$ の研究である. 家田らは, 計量心理学で言う弁別 闇 (Discrimination Threshold) の概念を導入し, 列車運行 時隔の異なる駅において通勤者の到着時刻を観測し，利 用者が当該駅での列車待ち時間を意識しているとみなせ るか否かを分析することで, 時間弁別閾值を導出した. ここで，弁別閾とは，識別可能な 2 つ刺激の大きさの 差の最小値で，丁度可知差異（JND: Just Noticeable Difference）とも呼ばれ，被験者に刺激差が $50 \%$ の正答率 で知覚される值を指す ら．家田らは，消費時間弁別閾は 平均で 5 分 24 秒であり, 約 1 分 16 秒で弁別率 $50 \%, 4$ 分で同 $75 \%, 11$ 分 14 秒で同 $90 \%$ という結果を得ている. ところがここでは，通勤者のアクセス行動に対して，(1) 通勤者のアクセス所要時間が，アクセス長分布と速度分 布から求められる特定の分布に従うこと，(2)通勤者は， 最寄駅到着後, 最初に出発する列車に乗ることを目標に, 自宅を出発していること，を仮定している．仮定(1)つ いては，各通勤者の実際のアクセス行動が仮定されるア クセス行動とは異なる可能性があり，また仮定(2につい ては，各通勤者の乗車希望列車に対して発生するスケジ ユール早着・遅延の費用が適切に評価されないという問 題点がある. そこで，以上の問題を克服し，より正確な 時間の意識限界を計測するため，本研究では，通勤者の 交通行動の観測と同時に，アンケート調査によってスケ ジュール費用を直接尋ねることにより，より実態に近い データを収集することとした。

\section{2. 本研究における時刻選択行動の基本的な考え方}

\section{(1)分析対象と適用するモデルと既往の時刻選択モデル}

本研究では，鉄道利用者の通勤行動における時刻選択 行動を対象に，列車待ち時間に対する時間意識の限界を 推定することとする．時刻選択モデルについては， Vickrey ${ }^{6}$ )以降，国内外で種々の定式化が行われてきてい る. 特に, Hall”が利用者は交通所要時間の不確害性を考 慮して余裕時間（セーフティーマージン）をもって時刻 選択行動をとっていると考えられることを示し，以降こ の考え方を念頭に置いた多くの分析が行われた. これら の一連の定式化で示されたのは，目的地への早着・遅延 
といったスケジュール費用によって出発時刻の効用が定 まるというモデルであった. ただし，これら研究の蓄積 は主に自動車交通を対象としたものである ${ }^{8,9,9,10)}$. 自家用 車を利用する場合, 就業地到着時刻は通勤者が選んだ自 宅出発時刻に直接依存することから, 通勤者は各到着時 刻のスケジュール費用を考慮の上, 自宅出発時刻を任意 に選択することができるという特性を持つ。一方で，本 研究では鉄道利用者を対象としている. この場合, 列車 は離散的に運行されているため, 就業地到着時刻は乗車 した列車によって定まり，単純に自宅の出発時刻が就業 地到着時刻と結びついているわけではない，鉄道利用者

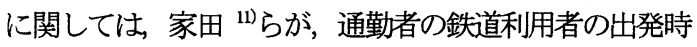
刻選択行動を定式化し，利用者の行動原理を解明してい る. だがここでも，鉄道の運行が離散的に行われている ために就業地到着時刻を任意の連続的な時刻から選択で きないという点については考慮されていない，そこで， 本研究では，鉄道の運行が離散的に行われていることを 明示的に考慮した利用者の自宅出発時刻選択行動を定式 化することとする.

\section{(2)本研究で仮定する通勤者の行動原理}

まず人間の行動原理として効用最大化を想定し，ラン ダム効用を仮定する.ここで通勤者の (間接) 効用関数 は，駅での列車待ち時間とスケジュール遅延または早着 のコストから構成されると仮定する.

なお金銭的費用については，少なくとも現在わが国の 鉄道サービスにおいては時刻によらず一定とみなしてよ いと考えられるため考慮しない.

自宅出発時刻 $i$ における個人 $n$ の効用 $U_{i n}$ を確定項 $V_{i n}$ と誤差項 $\varepsilon_{\text {in }}$ の和と考え，さらに確定項 $V_{i n}$ の基本式を以 下のように表す.

$$
V_{\text {in }}=a \bar{t}_{\text {win }}+b \bar{t}_{d d i n}+c \bar{t}_{e d i n}+d \bar{t}_{d p i n}+e \bar{t}_{\text {epin }}
$$

ここで, 自宅出発時刻 $i$ における個人 $n$ の

$\bar{t}_{w i n}:$ 駅での期待列車待ち時間

$\bar{t}_{d d i n}:$ 最終不遅刻列車期待スケジュール遅延

$\bar{t}_{\text {edin }}:$ 最終不遅刻列車期待スケジュール早着

$\bar{t}_{d p i n}:$ 乗車希望列車期待スケジュール遅延

$\bar{t}_{\text {epin }}:$ 乗車希望列車期待スケジュール早着

をそれぞれ表し，また $a, b, c, d, e$ : パラメータである.

なお，本研究では，就業地に遅刻せずに到着できる最後 の列車のことを「最終不遅刻列車」と呼び，心理的な余 裕を持つことができるため乗車することに決めている列 車（複数でも可）を「乗車希望列車」と呼ぶ．またスケ ジュール遅延は，当該列車よりも後に（遅く）発車する 列車に乗車した場合に発生し，スケジュール早着は，当 該列車よりも先に（早く）発車する列車に乗車するとき に発生するものとする． $\varepsilon_{i n}$ に i.i.d.ガンベルを仮定する と, 個人 $n$ が時刻 $i$ に自宅を出発する確率 $P_{i n}$ は式(2)のよ
うにMNLモデルとして表される.

$$
P_{i n}=\frac{e^{\lambda V_{i n}}}{\sum_{l} e^{\lambda V_{l}}}
$$

ここで， $\lambda$ : 誤差の分散にかかわるパラメータである.

\section{（3)各変数の定義と求め方}

まず，時刻 $i$ に自宅を出発し，時刻 $j$ に最寄駅に到着 する個人 $n$ の総通勤所要時間 $t_{i j n}$ は, 以下のように表され る.

$$
\begin{aligned}
& t_{i j n}=t_{a j i n}+t_{w j n}+t_{r j n}+t_{e j n} \\
& \text { ここで, } \\
& t_{a j n}: \text { アクセス所要時間 } \\
& t_{w j n}: \text { 列車待ち時間 } \\
& t_{r j n} \text { : 列車乗車時間（乗換時間含む） } \\
& t_{\text {ejn }}: \text { イグレス所要時間 }
\end{aligned}
$$$$
\text { である. }
$$

利用者は駅に到着後最初に発車する列車に乗車すると いう仮定を置き，列車待ち時間 $t_{w j n}$ を

$$
t_{w j n}=T_{d j n}-j_{n}
$$

によって求める. ここで $T_{d j n}$ とは, 当該駅で時刻 $j_{n}$ より 後に最初に到着する列車の発車時刻を指し，観測により データを得ることとする.

次に, 列車発車時刻 $T_{d j n}$ については, 通勤所要時間か ら以下の関係が成り立つ.

$$
T_{d j n}=T_{o n}-\left(t_{r j n}+t_{e j n}\right)
$$

ここで, $T_{o n}$ : 就業地到着時刻である.

なお，我が国の都市鉄道ではその所要時間は時刻によ らず概ね一定であり，また多くの通勤者のイグレス手段 が徒歩と考えられることから，その所要時間の変動は無 視できるほど小さいものとみなす，すると，乗車後の所 要時間は時刻によらず一定となる. その結果, 通勤者の 自宅出発時刻選択問題は, 最寄駅到着時刻により発生す るトータルコストの最小化問題としてとらえることがで きる.このとき，トータルコストに影響を与えるのは， 最終不遅刻列車の発車時刻 $T_{d d n}$ 及び乗車希望列車の発車

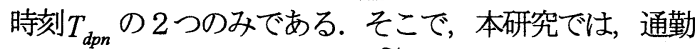
者の最寄駅到着時刻の実績值 $\widetilde{j}_{n}$ の観測と同時にアンケ 一ト調査票を配布し, $T_{d d n}, T_{d p n}$ のデータを入手するも のとする.

なお，最寄駅到着時刻 $j$ におけるスケジュール費用は それぞれ以下のように表される.

$$
\begin{aligned}
& t_{d d j n}=\left\{\begin{array}{l}
T_{d j n}-T_{d d n}: \text { If } T_{d j n}>T_{d d n} \\
0: \text { otherwise }
\end{array}\right. \\
& t_{\text {edjn }}=\left\{\begin{array}{l}
T_{d d n}-T_{d j n}: \text { If } T_{d d n}>T_{d j n} \\
0: \text { otherwise }
\end{array}\right.
\end{aligned}
$$




$$
\begin{aligned}
t_{d p j n} & =\left\{\begin{array}{l}
T_{d j n}-T_{d p n}: \text { If } T_{d j n}>T_{d p n} \\
0: \text { otherwise }
\end{array}\right. \\
t_{e p j n} & =\left\{\begin{array}{l}
T_{d p n}-T_{d j n}: \text { If } T_{d p n}>T_{d j n} \\
0: \text { otherwise }
\end{array}\right.
\end{aligned}
$$

ここで, 最寄駅到着時刻 $j$ における個人 $n$ の

$t_{d d j n}:$ 最終不遅刻列車スケジュール遅延

$t_{\text {edjn }}:$ 最終不遅刻列車スケジュール早着

$t_{d p j n}:$ 乗車希望列車スケジュール遅延

$t_{e p j n}:$ 乗車希望列車スケジュール早着

を表すななお，各スケジュール費用について概念図的に 表したものが図-1である.

\section{(4)駅到着時刻の確率的変動の考慮}

日々の通勤においては，その日の交通状況などが於 セス所要時間を変動させ, 通勤者の最寄駅到着時間に影 響を与えていると考えられる. 一方で, 観測調查から得 られるのは, 特定の 1 日の各通勤者の最寄駅到着時刻の 実績值 $\widetilde{j}_{n}$ のみである. そこで，本研究では，観測結果 の最寄駅到着時刻に，アンケートの回答を基にした確率 的な分布を与えることで，アクセス所要時間の変動を考 慮した分析を行うこととした.

アンケート調査では, 被験者に対して平均的なアクセ ス所要時間 $\bar{t}_{a n}$ を尋ねている. すると最寄駅到着時刻の 観測值 $\tilde{j}_{n}$ より, 自宅出発時刻は

$$
\hat{i}_{n}=\widetilde{j}_{n}-\bar{t}_{a n}
$$

と推定される.

一方で, アンケート調査ではアクセス所要時間の最大 值 $t_{\text {anMAX }}$, 最小值 $t_{\text {anMIN }}$ も同時に尋ねている. そこで, これをもとにアクセス所要時間の確率密度分布を与える ことで, その変動を考慮することとする. 本研究では, 操作の容易性を考慮し， $\bar{t}_{a n}$ に最頻值を持つ， $\boldsymbol{t}_{\text {anMIN }} \leq \boldsymbol{t}_{\text {an }} \leq \boldsymbol{t}_{\text {anMAX }}$ の範囲の三角分布とした（図-2）. すると，通勤者が時刻 $\hat{i}_{n} に$ 出発したときに，駅に到着 し得る時刻は,

$$
\hat{i}_{n}+t_{\text {anMIN }} \leq j \leq \hat{i}_{n}+t_{\text {anMAX }}
$$

となる. この全ての $j$ に対し，式(4)から列車待ち時間， 式(6)-(9)からスケジュール費用がそれぞれ求まる. 同様 にして全ての出発時刻に対して, 同一のアクセス所要時 間分布を仮定すると, ある時刻 $i$ に出発したときの列車 待ち時間，スケジュール費用の期待值は，それぞれ以下 のようになる.

$$
\bar{t}_{\text {win }}=\sum_{j=i+t_{\text {ondAN }}}^{i+t_{\text {ona }}} q_{n}(j \mid i) \cdot t_{\text {wjn }}
$$

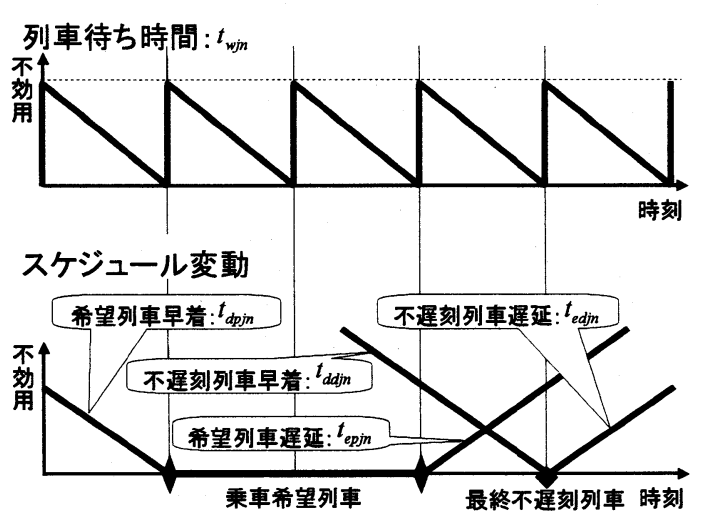

図-1 各説明変数の関係の模式図

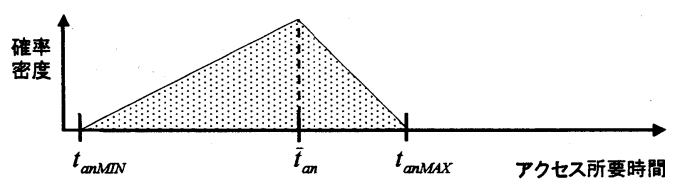

図-2 アクセス所要時間の確率密度分布

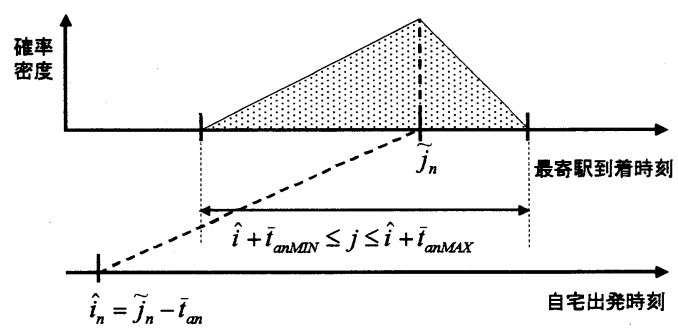

図-3 アクセス所要時間変動を考慮した最奇駅到着時刻

$$
\begin{aligned}
& \bar{t}_{d d j n}=\sum_{j=i+t_{\text {ondAv }}}^{i+t_{\text {onkax }}} q_{n}(j \mid i) \cdot t_{d d j n} \\
& \bar{t}_{e d j n}=\sum_{j=i+t_{\text {endAN }}}^{i+t_{\text {onnax }}} q_{n}(j \mid i) \cdot t_{\text {edjn }} \\
& \bar{t}_{d p j n}=\sum_{j=i+t_{\text {oundav }}}^{i+t_{\text {ondax }}} q_{n}(j \mid i) \cdot t_{d p j n} \\
& \bar{t}_{e p j n}=\sum_{j=i+t_{\text {enda }}}^{i+t_{\text {nnuax }}} q_{n}(j \mid i) \cdot t_{\text {epjn }}
\end{aligned}
$$

ここで, $q_{n}(j \mid i)$ は，個人 $n$ 自宅を時刻 $i$ に出発すると いう条件下において, 時刻 $j$ に最寄駅に到着する確率を 表す。

\section{3. テータの収集およびパラメータ推計}

\section{(1)デ一タの収集}

データ収集のため, 首都圈の14の通勤鉄道駅を対象に, 通勤者の駅到着時刻の観測およびアンケート調査を実施 
表-1 調査の概要ならびに平均運行時隔

\begin{tabular}{|c|c|c|c|c|c|c|c|}
\hline 害查日時 & 2001年) & 路線名 & 駅名 & 調查箇所(入口名) & 平均運行時陰 & サンプル数 & Pンケート回収枚数 \\
\hline 10 月 24 (一) & $7: 40-9: 00$ & 学用南北綿 & エ子神公 & $\frac{\text { 1番入口・前半 }}{\text { 2番入口・前半 }}$ & 251 秒 & 337 & 74 \\
\hline 10月 & $9: 00-9: 50$ & 呂凹けー称 & 种石 & $\frac{\text { 1番入口・後半 }}{\text { 2番入口・後半 }}$ & 360 秒 & 37 & 15 \\
\hline 11月7日(水) & $7: 20-8: 10$ & 東武東上線 & 大山 & 池袋方面行 & 270 秒 & 75 & 12 \\
\hline 11月/日(水) & $7: 20-8: 20$ & 東急世田谷線 & 世田谷 & 三軒茶屋方面行 & 266 秒 & 64 & 37 \\
\hline & $7: 20-8: 40$ & 東急多摩川線 & 鵜の木 & 多摩川方面行 & 206 秒 & 115 & 25 \\
\hline & $7: 10-8: 40$ & & & 五反田方面行 & 304 秒 & 80 & 24 \\
\hline 11月8日（木） & $7: 50-9: 10$ & 果急池上称 & 久が原 & 蒲田方面行 & 330 秒 & 164 & 43 \\
\hline & $7: 30-8: 50$ & 東急池上線 & 戸越銀座 & 五反田方面行 & 167 秒 & 38 & 15 \\
\hline 11月 14 月(水) & $7: 20-8: 40$ & 営団日比谷線 & 入谷 & 中目黒方面行 & 127 秒 & 93 & 37 \\
\hline 11月 14 日(水) & $7: 30-8: 20$ & 小田急小田原䊽 & 参宮橋 & 新宿方面 & 373 秒 & 27 & 20 \\
\hline & $7: 20-8: 40$ & 東武亀戸線 & 東あずま & $=$ & 300 秒 & 81 & 23 \\
\hline 11月 15 日(水) & $\frac{7: 20-8: 40}{7: 30-8: 23}$ & 京成押上線 & 京成曳舟 & 押上方面行·押上方入口 & 296秒 & 90 & 43 \\
\hline & $7: 40-8: 30$ & 京成金町線 & 柴又 & & 600 秒 & 117 & 19 \\
\hline 11月 20 日(水) & $7: 20-8: 50$ & 東急大井町線 & 戸越公園 & 大井町方面行 & 211秒 & 40 & 19 \\
\hline & $7: 30-9: 10$ & & 原远公还 & 子玉川方面行 & 218 秒 & 38 & 29 \\
\hline 11月 21 & $7: 10-8: 30$ & 酉武新宿線 & 下落合 & 酉武新宿行 & 380 杪 & 48 & 11 \\
\hline 11月27日(火) & $7: 50-9: 00$ & 京急大師線 & 港町 & & 300 秒 & 12 & 7 \\
\hline
\end{tabular}

表-2 調查方法の概要

\begin{tabular}{|c|c|}
\hline $\begin{array}{c}\text { 調查者 } 1 \\
\text { 調查票配布 }\end{array}$ & (1)番号を付したアンケート調査票の配布（郵送による回収） \\
\hline 調查者 2 & $\begin{array}{l}\text { 時刻および人数計測を行うプログラムを作成の上、ノートPCを用いて } \\
\text { (1)ンケート調査票が受け取られた時刻と受け取られた調査票の番号の記録 } \\
\text { (2)アンケート調查票受け取り者を含む全通勤者の到着時刻の記録 }\end{array}$ \\
\hline
\end{tabular}

した. アンケート調査では，駅到着者の一部に対しての 調査票を配布し, 各通勤者の行動の前提となる諸条件

(利用目的, 鉄道利用総所要時間, アクセス・イグレス 所要時間, 始業時刻, 最終不遅刻列車, 乗車希望列車な ど）の情報を入手した.

調查対象駅ならびに対象時間帯の選定に当たっては, (1)平日朝の通勤時間帯において, 列車の運行時隔が一定 であること, (2)各列車のサービス水準 (列車種別, 行先, 着席可能性など）が対象駅間でほぼ均一であること, (3) 駅到着者の到着時刻測定が容易であること, などを考慮 し，表一のような駅・時刻で調査を実施した．また調査 の方法の詳細は表-2の通りである.

\section{(2)パラメ一夕推定方法}

観測とアンケートから得たデータを用いてモデルパラ メータの推定を行う.

推定にあたっては，離散選択モデルを適用するため， 観測された通勤者の駅到着時刻を, 毎分 00 秒, 30 秒を 中心とする 45-15 秒, 15-45 秒の 30 秒ごとの時刻帯に それぞれ離散化した. これは, 一般に鉄道事業者が列車 遅延などの運行状況を把握する際の最小単位が, ダイヤ 上の定時士 15 秒 (=30 秒) であることに倣ったためで ある. 具体的なパラメー夕推定は, 以下の尤度関数の最 大化により行った.

$$
L(a, b, c, d, e)=\prod_{n} \prod_{i} \prod_{j} w_{j m n} \cdot\left[q_{n}(j \mid i) \cdot P_{i n}\right]^{q_{n}(j \mid i)}
$$$$
\text { ここで, } w_{j m n} \text { : サンプル } n \text { が } m \text { 駅で時刻 } j \text { に観測さ }
$$
れるとき, $m$ 駅時刻 $j$ におけるサンプル抽出率 $(=m$ 駅時刻 $j$ でのアンケート回収数/時刻 $j$ における $m$ 駅 への全到着数）の逆数である. また，以上のような WESML 推定を行ったのは, 観測した駅や時刻によって アンケート調査票配布率や回収率が異なるためである.

\section{4. 時刻選択モデルの推定結果}

\section{(1)パラメ一タ推定とモデルの選択}

まず，調査の結果得られた1456サンプル全てに対して， 効用関数に式(1)を用いて場合（モデル1）のモデルパラ メータの推定結果は，表-3の通りである. この結果を見 ると, $\bar{t}_{d d j n}$ のパラメータが正になるなど, モデルの仮定 之整合的でない部分がある. これは各説明変数間，特に 最終不遅刻列車スケジュール遅延と乗車希望列車スケジ ユール遅延の間で相関が原因と考えられる. また実際に パラメータ推定結果からも, 説明変数 $\left(\bar{t}_{d d j n}, \bar{t}_{d p j n}\right)$ 間の相 関係数がー0.749と高い值となっていることが確認された.

この点を鑑み, より適切な組み合わせの説明変数を見 出すため, 説明変数の組み合わせをいろいろと変化させ てみることにした.

モデル 1 の推定に用いられている説明変数は列車待ち 
時間，スケジュール遅延，スケジュール早着の 3 つ大 別され，スケジュール遅延及び早着についてはそれぞれ 対象列車が最終不遅刻列車と乗車希望列車となっている ものがある.

そこで，まずスケジュール遅延またはスケジュール早 着から1つを取り除き，列車待ち時間とあわせて4説明変 数でパラメータ推定を行った.

効用関数に組み込む説明変数の組み合わせはそれぞれ

モデル2: $\left(\bar{t}_{w i n}, \bar{t}_{e d j n}, \bar{t}_{d p j n}, \bar{t}_{e p j n}\right)$

モデル3: $\left(\bar{t}_{w i n}, \bar{t}_{d d j n}, \bar{t}_{d p j n}, \bar{t}_{e p j n}\right)$

モデル4 : $\left(\bar{t}_{w i n}, \bar{t}_{d d j n}, \bar{t}_{e d j n}, \bar{t}_{e p j n}\right)$

モデル5 : $\left(\bar{t}_{\text {win }}, \bar{t}_{d d i n}, \bar{t}_{e d i n}, \bar{t}_{d p j i}\right)$

とし，そのパラメータ推定結果を示したのが表-4である. その結果からモデル2のときに相対的に説明力が最も高 くなっていることが分かる.これは表-3の結果において 最も有意度が低い説明変数 $\bar{t}_{d d j n}$ を取り除いて推定したも のであることを鑑みれば整合的であると言える.なお, 説明変数の組み合わせがモデル4の場合については適切 にパラメータ推定が行えなかった。

次いで，スケジュール遅延，スケジュール早着からそ

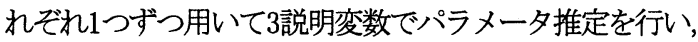
モデル説明力からより望ましい説明変数の組み合わせを 検討した. これは $\left(\bar{t}_{d d j n}, \bar{t}_{d p j n}\right)$ または $\left(\bar{t}_{e d j n}, \bar{t}_{e p j n}\right)$ というよ うなスケジュール遅延同士やスケジュール早着同士の説 明変数間では相関が高いことが問題になると考えられる からである. そこで効用関数に組み込む説明変数の組み 合わせをそれぞれ

$$
\begin{aligned}
& \text { モデル6:( } \left.\bar{t}_{w i n}, \bar{t}_{d p j n}, \bar{t}_{e p j n}\right) \\
& \text { モデル7 : }\left(\bar{t}_{w i n}, \bar{t}_{e d j n}, \bar{t}_{d p j n}\right) \\
& \text { モデル8 : }\left(\bar{t}_{w i n}, \bar{t}_{d d j n}, \bar{t}_{e p j n}\right)
\end{aligned}
$$

モデル9 : $\left(\bar{t}_{w i n}, \bar{t}_{d d j n}, \bar{t}_{e d j i}\right)$

とし，パラメータ推定した結果が表-5である. 相対的に 見て説明変数がモデル6が最も説明力が高い，一方で説 明変数に $\bar{t}_{d p j n}$ を含まない組み合わせではその説明力が低 いことが分かる. なおモデル9に関しては，パラメータ 推定が適切に行えなかった。

\section{(2)パラメ一夕推定結果に基づく考察}

表-4，表-5から分かる通り， $\bar{t}_{d d j i n}, \bar{t}_{d p j n}$ をともに説明 変数として入れてパラメータ推定した場合, 両者の相関 関係が高いためか，特に $\bar{t}_{d d j n}$ のパラメータが整合的でな かったり， $\bar{t}_{d d j n}$ と $\bar{t}_{d p j n}$ の有意度を比較すると $\bar{t}_{d d j n}$ のそれ が低かったりすることが見てとれる．このことから，通 勤者はスケジュール遅延に関して主に $\bar{t}_{d p j n}$ を考慮してい るものと考えられる. =方で, $\bar{t}_{e d j n}, \bar{t}_{e p j n}$ については両 者を説明変数に取り込えでも，パラメータの推定結果は 整合的であり，通勤者が $\bar{e}_{e d j n}, \bar{t}_{e p j n}$ をともに考慮してい るものと考えられる.

以上の結果から，通勤鉄道利用者の出発時刻選択行動 をMNLモデルを用いて分析した結果を考察すると，利用

\begin{tabular}{|c|c|c|c|}
\hline \multirow[b]{2}{*}{ 説明変数 } & & \multicolumn{2}{|c|}{ モデル1 } \\
\hline & & パラメータ & $\mathrm{t}$ t值 \\
\hline 待ち時間 & (秒) & -0.00402 & $-11.0)$ \\
\hline 遅延: 不遅刻 & $\overline{\mathrm{t}}_{\mathrm{d} d}$ (秒) & 0.00059 & 2.0 ) \\
\hline 早着:不遅刻 & $\overline{\mathrm{t}}_{\text {ed }}$ (秒) & -0.00124 & $-9.1)$ \\
\hline 遅延:希望 & $\bar{t}_{d_{p}}$ (秒) & -0.00402 & $-15.6)$ \\
\hline 早着:希望 & $\overline{\mathrm{t}}_{\mathrm{ep}}$ （秒） & -0.00423 & $-10.4)$ \\
\hline 初期尤度 & & -17160 & \\
\hline $\begin{array}{c}\text { 最終尤度 } \\
\text { DF嘼整龙度比 }\end{array}$ & & $\begin{array}{r}-4716.8 \\
0.098\end{array}$ & \\
\hline
\end{tabular}
者の行動に関して以下のような特徵が推察される.

\section{表-3 全説明変数を用いたパラメ一タ推定結果}

\begin{tabular}{|c|c|c|c|c|c|c|c|}
\hline \multirow[b]{2}{*}{ 説明変数 } & & \multicolumn{2}{|c|}{ モデル2 } & \multicolumn{2}{|c|}{ モデル3 } & \multicolumn{2}{|c|}{ モデル5 } \\
\hline & & パラメータ & $\mathrm{t}$ 值 & パラメータ & $\mathrm{t}$ 值 & パラメータ & $\mathrm{t}$ 值 \\
\hline 待ち時間 & $\overline{\bar{t}_{w}}$ (秒) & -0.00402 & $-10.9)$ & -0.00403 & $-11.0)$ & -0.00385 & $-10.5)$ \\
\hline 遅延:不遅刻 & $\bar{t}_{d d} \quad($ 秒 $)$ & - & & -0.00022 & $-0.8)$ & 0.00132 & $4.6)$ \\
\hline 早着:不遅刻 & $\bar{t}_{\text {ed }}$ (秒) & -0.00116 & $-9.0)$ & - & $-\quad)$ & -0.00218 & $-18.0)$ \\
\hline 遅延:希望 & $\bar{t}_{d p}$ (秒) & -0.00365 & $-21.2)$ & -0.00270 & $-12.3)$ & -0.00476 & $-19.1)$ \\
\hline 早着:希望 & $\bar{t}_{\mathrm{ep}}$ (秒) & -0.00437 & $-10.9)$ & -0.00589 & $-16.1)$ & - & \\
\hline 初期尤度 & & -5227.3 & & -5227.3 & & -5227.3 & \\
\hline 最終尤度 & & -4718.7 & & -4761.9 & & -4784.6 & \\
\hline DF調整济尤度比 & & 0.097 & & 0.089 & & 0.085 & \\
\hline
\end{tabular}

表-4 4 説明变数を用いたパラメ一夕推定結果

\begin{tabular}{|c|c|c|c|c|c|c|c|c|}
\hline \multirow[b]{2}{*}{ 説明変数 } & & & \multicolumn{2}{|c|}{ モデル6 } & \multicolumn{2}{|c|}{ モデル7 } & \multicolumn{2}{|c|}{ モデル8 } \\
\hline & & & パラメータ & $\mathrm{t}$ 值 & パラメータ & $\mathrm{t}$ 值 & パラメータ & $\mathrm{t}$ 値 \\
\hline 待ち時間 & $\overline{\bar{t}_{w}}$ & (秒) & -0.00403 & $(-11.0)$ & -0.00381 & $-10.4)$ & -0.00399 & $(-10.9)$ \\
\hline 遅延: 不遅刻 & $\bar{t}_{d d}$ & (秒) & - & - & - & - & -0.00307 & $-16.4)$ \\
\hline 早着:不遅刻 & & (秒) & - & & -0.00204 & $-17.9)$ & - & - \\
\hline 遅延:希望 & & (秒) & -0.00283 & $-19.6)$ & -0.00398 & -22.9 ) & - & $-\quad)$ \\
\hline 早着:希望 & $\overline{\mathrm{t}}_{\mathrm{ep}}$ & (秒) & -0.00588 & $-16.1)$ & - & & -0.00547 & $-15.1)$ \\
\hline 初期尤度 & & & $\begin{array}{l}-5227.3 \\
-4762.2\end{array}$ & & $\begin{array}{l}-5227.3 \\
-4795.4\end{array}$ & & $\begin{array}{l}-5227.3 \\
-4870.0\end{array}$ & \\
\hline 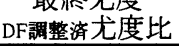 & & & $\begin{array}{r}-4 / 02.2 \\
0.089 \\
\end{array}$ & & $\begin{array}{r}-4 / 90.4 \\
0.083\end{array}$ & & $\begin{array}{r}-48 / 0.0 \\
0.068\end{array}$ & \\
\hline
\end{tabular}

表-5 3 説明変数を用いたパラメ一夕推定結果 
(1) 通勤者は, 所要時間の変動などを考慮してセーフテ イーマージンを持つ乗車希望列車を想定し，その列 車に対するスケジュール費用を重視する傾向にある.

(2) スケジュール遅延に関しては，最終不遅刻列車と最 も遅い乗車希望列車が合致するもしくは近い場合が 多小!

（3) 通勤者は, 出発時刻選択の際, 最終不遅刻列車のス ケジュール遅延費用より，乗車希望列車のスケジュ 一ル遅延費用を強く考慮している.

(4) 最終不遅刻列車のスケジュール早着費用と乗車希望 列車のスケジュール装着費用との相関は低く，最終 不遅刻列車よりかなり早い時刻の列車からでも乗車 希望列車となっていることがある.

(5) 通勤者は, 出発時刻選択の際, 最終不遅刻列車のス ケジュール早着と乗車希望列車のスケジュール早着 を別のものと考え，それらをともに重視している.

以上を総合すると，通勤鉄道利用者の自宅出発時刻選 択行動において, 通勤者は主に, 列車待ち時間, 乗車希
望列車スケジュール遅延, 最終不遅刻列車スケジュール 早着, 乗車希望列車スケジュール早着を考慮していると 説明できると考えられる. そこで，本研究では，時間差 に対する意識限界を計測する上で用いる時刻選択モデル に，モデル2を用いることとした.

\section{5. 時刻選択モデルを用いた列車待ち時間意識限界の試算}

\section{(1)時間意識限界の分析手法}

前章の結果から，時刻選択モデルの効用関数に以下の 式（モデル2）を用いる.

$$
V_{\text {in }}=a^{\prime} \bar{t}_{\text {win }}+b^{\prime} \bar{t}_{d d i n}+c^{\prime} S \bar{t}_{d p i n}+d^{\prime} \bar{t}_{\text {epin }}
$$

なお $a^{\prime}, b^{\prime}, c^{\prime}, d^{\prime}$ はパラメータである.

ここで，列車待ち時間に対する意識限界を知るために， サンプルを，そのサンプル通勤者の利用する駅を運行時 隔の長短により2つのセグメントにわけ，その境界を順 次変化させてセグメントごとにパラメータ推定すること とする. その上で, 列車待ち時間に関するパラメータの

\section{表-6 時刻選択モデルのパラメ一タ推定結果}

\begin{tabular}{|c|c|c|c|c|c|c|c|c|}
\hline 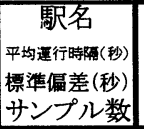 & $\begin{array}{l}\text { 入谷 } \\
127 \\
20 \\
\\
93 \\
\end{array}$ & $\begin{array}{c}\text { 戸越銀座 } \\
167 \\
44 \\
131\end{array}$ & $\begin{array}{c}\text { 鵜の木 } \\
206 \\
51 \\
246\end{array}$ & $\begin{array}{l}\text { 越公園大井町 } \\
211 \\
31 \\
286\end{array}$ & $\begin{array}{l}\text { 公圆二子王川 } \\
218 \\
43 \\
324\end{array}$ & $\begin{array}{l}\text { 子神谷前半 } \\
251 \\
32 \\
661\end{array}$ & $\begin{array}{l}\text { 世田谷 } \\
266 \\
31 \\
\quad 725\end{array}$ & $\begin{array}{l}\text { 大山 } \\
270 \\
42 \\
800\end{array}$ \\
\hline $\begin{array}{l}\text { パラメータ } \\
\text { 待ち時間 } \\
\text { 早着:不遅刻 } \\
\text { 遅延:希望 } \\
\text { 早着:希望 }\end{array}$ & $\begin{array}{l}.01295 \\
.00187 \\
.01178 \\
0.01977\end{array}$ & $\begin{array}{r}0.00075 \\
-0.00156 \\
-0.00826 \\
-0.00524\end{array}$ & $\begin{array}{l}-0.00104 \\
-0.00270 \\
-0.00732 \\
-0.00363\end{array}$ & $\begin{array}{l}-0.0 \\
-0.0 \\
-0.0\end{array}$ & $\begin{array}{l}10 \\
11 \\
80 \\
44\end{array}$ & $\begin{array}{l}87 \\
27 \\
76 \\
30\end{array}$ & $\begin{array}{l}-0.00157 \\
-0.00113 \\
-0.00554 \\
-0.00564\end{array}$ & $\begin{array}{r}0.00050 \\
-0.00121 \\
-0.00560 \\
-0.00548\end{array}$ \\
\hline $\begin{array}{c}\mathrm{t} \text { 值 } \\
\text { 待ち時間 } \\
\text { 早着:不遅刻 } \\
\text { 遅延:希望 } \\
\text { 早着:希望 }\end{array}$ & $\begin{array}{l}-2.489 \\
-2.999 \\
-5.434 \\
-2.669\end{array}$ & $\begin{array}{r}0.243 \\
-3.007 \\
-6.978 \\
-3.476\end{array}$ & $\begin{array}{r}-0.569 \\
-7.561 \\
-11.157 \\
-3.368\end{array}$ & $\begin{array}{r}-0.134 \\
-7.123 \\
-11.231 \\
-3.707\end{array}$ & $\begin{array}{r}-1.348 \\
-7.290 \\
-11.868 \\
-3.197\end{array}$ & $\begin{array}{r}-0.904 \\
-6.177 \\
-16.734 \\
-8.896\end{array}$ & $\begin{array}{r}-1.789 \\
-6.029 \\
-17.180 \\
-9.657\end{array}$ & $\begin{array}{r}-0.641 \\
-6.572 \\
-18.414 \\
-9.886\end{array}$ \\
\hline \begin{tabular}{|c|} 
初期尤度 \\
最終尤度 \\
尤度比 \\
自由度䔃整尤度比
\end{tabular} & $\begin{array}{r}-374.56 \\
-294.54 \\
0.214 \\
\mathbf{0 . 2 1 3} \\
\end{array}$ & $\begin{array}{r}-525.21 \\
-447.13 \\
0.149 \\
0.148 \\
\end{array}$ & $\begin{array}{r}-1000.95 \\
-853.66 \\
0.147 \\
0.147 \\
\end{array}$ & $\begin{array}{r}-1147.37 \\
-996.83 \\
0.131 \\
0.131 \\
\end{array}$ & $\begin{array}{r}-1298.32 \\
-1140.93 \\
0.121 \\
0.121 \\
\end{array}$ & $\begin{array}{r}-2622.48 \\
-2306.86 \\
0.120 \\
0.120 \\
\end{array}$ & $\begin{array}{r}-2862.80 \\
-2525.68 \\
0.118 \\
0.118 \\
\end{array}$ & $\begin{array}{r}-3163.95 \\
-2778.71 \\
0.122 \\
0.122 \\
\end{array}$ \\
\hline 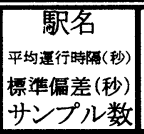 & $\begin{array}{c}\text { 京成更舟 } \\
296 \\
33 \\
890\end{array}$ & $\begin{array}{c}\text { 東あずま } \\
300 \\
0 \\
971\end{array}$ & $\begin{array}{l}\text { 港町 } \\
300 \\
0 \\
983\end{array}$ & $\begin{array}{c}\text { 久が原五反田 } \\
304 \\
60 \\
1063\end{array}$ & $\begin{array}{c}\text { 久が原蒲田 } \\
330 \\
31 \\
1227\end{array}$ & $\begin{array}{c}\text { 王子神谷後半 } \\
360 \\
0 \\
1264\end{array}$ & $\begin{array}{c}\text { 参宮橋 } \\
373 \\
40 \\
1291\end{array}$ & $\begin{array}{c}\text { 下落合 } \\
380 \\
74 \\
1339 \\
\end{array}$ \\
\hline $\begin{array}{l}\text { パラメータ } \\
\text { 待ち時間 } \\
\text { 早着:不遅刻 } \\
\text { 遅延:希望 } \\
\text { 早着:希望 }\end{array}$ & $\begin{array}{l}-0.00200 \\
-0.00161 \\
-0.00452 \\
-0.00398\end{array}$ & $\begin{array}{l}-0.00191 \\
-0.00171 \\
-0.00453 \\
-0.00410\end{array}$ & $\begin{array}{l}-0.00164 \\
-0.00172 \\
-0.00454 \\
-0.00410\end{array}$ & $\begin{array}{l}-0.00 \\
-0.00 \\
-0.00\end{array}$ & $\begin{array}{l}15 \\
57 \\
68 \\
76\end{array}$ & $\begin{array}{l}-0.0 \\
-0.0 \\
-0.0\end{array}$ & $\begin{array}{l}-0.00322 \\
-0.00158 \\
-0.00359 \\
-0.00483\end{array}$ & $\begin{array}{l}-0.00289 \\
-0.00147 \\
-0.00361 \\
-0.00507\end{array}$ \\
\hline $\begin{array}{c}\mathrm{t} \text { 值 } \\
\text { 待ち時間 } \\
\text { 早着:不遅刻 } \\
\text { 遅延:希望 } \\
\text { 早着:希望 }\end{array}$ & $\begin{array}{r}-2.866 \\
-8.987 \\
-18.870 \\
-8.040\end{array}$ & $\begin{array}{r}-2.969 \\
-10.069 \\
-20.077 \\
-8.421\end{array}$ & $\begin{array}{r}-2.596 \\
-10.162 \\
-20.244 \\
-8.450\end{array}$ & $\begin{array}{r}-3.519 \\
-10.769 \\
-21.091 \\
-8.935\end{array}$ & $\begin{array}{r}-5.859 \\
-10.686 \\
-20.893 \\
-10.302\end{array}$ & $\begin{array}{r}-6.076 \\
-10.744 \\
-20.955 \\
-10.462\end{array}$ & $\begin{array}{r}-6.312 \\
-11.032 \\
-21.205 \\
-10.534\end{array}$ & $\begin{array}{r}-5.986 \\
-10.667 \\
-21.575 \\
-11.054\end{array}$ \\
\hline \begin{tabular}{|c|} 
初期尤度 \\
最終尤度 \\
尤度比 \\
自由度喠整尤度比
\end{tabular} & $\begin{array}{r}-3514.27 \\
-3163.18 \\
0.100 \\
0.100\end{array}$ & $\begin{array}{r}-3838.25 \\
-3440.55 \\
0.104 \\
0.104\end{array}$ & $\begin{array}{r}-3886.89 \\
-3484.10 \\
0.104 \\
0.104\end{array}$ & $\begin{array}{r}-4184.74 \\
-3742.42 \\
0.106 \\
\mathbf{0 . 1 0 6}\end{array}$ & $\begin{array}{r}-4738.58 \\
-4308.68 \\
0.091 \\
0.091 \\
\end{array}$ & $\begin{array}{r}-4891.96 \\
-4456.61 \\
0.089 \\
0.089\end{array}$ & $\begin{array}{r}-5003.02 \\
-4556.15 \\
0.089 \\
\mathbf{0 . 0 8 9} \\
\end{array}$ & $\begin{array}{r}-5202.41 \\
-4735.05 \\
0.090 \\
0.090 \\
\end{array}$ \\
\hline
\end{tabular}

注 1：「駅名」はパラメータ推定に用いたサンプル通勤者の利用する駅の中で最大の平均運行時隔の駅を指す.

注 2 : 駅名の項目中， 0 内は複数の入口・時刻で調查を行った駅でのそれぞれ入口名及ひ時刻を示す. 
サンプルに含まれる最大平均運行時隔(秒)

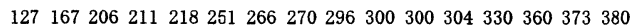

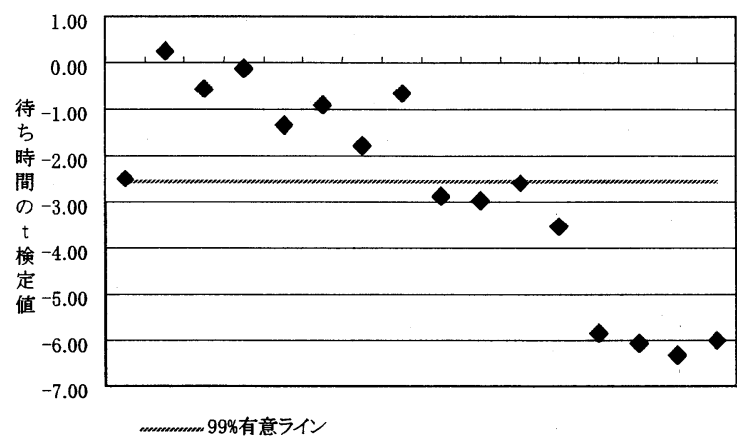

図-4 期待列車待ち時間変数の $\mathrm{t}$ 検定値の推移

統計的検定を用い，その有意性の有無から意識限界を推 定する. 推定においては前章と同様にWESML推定を行 った.

\section{(2)時間意識限界の推計結果及び考察}

運行時隔の短い駅から順にサンプルを増やしていった ときのモデルパラメータの推計結果は表-6 の通りである. 各変数の符号については一部の例外を除くと，ほほ整合 的な結果が得られていることがわかる.

次に，モデルの適合度（自由度調整済み尤度比）を見 ると，概して運行時隔の長いサンプルが増えるにつれて， 徐々に低下していくことが分かる.これは列車待ち時間 に対する意識の差があるといら行動原理が異なるサンプ ルがより多く混合することによって生じるものと考えら れる.

次に, 列車待ち時間変数の $\mathrm{t}$ 検定值を各セグメントパ ターンについて示したものが図-4である. これより，運 行時隔が短い方のセグメントに含まれる駅の平均運行時 隔が全て 4 分 30 秒（270秒）以下の場合，列車待ち時間 パラメータ $a^{\prime}$ の $\mathrm{t}$ 値は $99 \%$ 有意值より低く, 選択行動 の際に意識されていないと言える. その反面，セグメン 卜に平均運行時隔が 4 分 56 秒 (296 秒) 以上の駅が含ま れる場合， $a^{\prime}$ が統計的に有意となり，列車待ち時間が 意識されるようになっていることが分かる.

以上の結果から，通勤交通行動において，列車待ち時 間が意識されるか否かの限界は平均運行時隔で約 4 分 30 秒 4 分 56 秒の間であると推察される. この值は, 利用 者が駅一列車待ち時間を意識することなく, ランダムに 到着する場合の期待列車待ち時間が約 2 分 20 秒程度で あることを意味する.この結果は，先行研究である家田 ら 4によっつ求められた時間弁別間值の推計結果より, かなり短、值となっていることが分かる.これは，家田 らの研究では，通勤者にスケジュール変動に対する費用 は発生しないと仮定されているため，実際にはある列車
に乗り遅れた通勤者であったとしても，見かけ上次の列 車に向けてかなり早く駅に到着したと観測されてしまい， 結果時間弁別閾值が実際より長く推計されてしまうこと が原因と考えられる.

\section{6. おわりに}

\section{(1)結論}

本研究では，鉄道通勤利用者の自宅出発時刻選択行動 を，駅での到着時刻観測データと，同時に実施したアン ケート調査による通勤者の外生的時刻制約条件のデータ とを用いて分析した. MNL モデルに基づく時刻選択モ デルを構筑した結果，通勤鉄道利用者の自宅出発時刻選 択行動においては, 列車待ち時間, 乗車希望列車のスケ ジュール遅延, 乗車希望列車と最終不遅刻列車のスケジ ユール早着，が主に考慮されていることがわかった。

またこのモデルを用いて，通勤者が列車待ち時間を意 識しているか否かを列車待ち時間のパラメータの統計的 な有意性から判定した結果，駅における平均列車運行時 隔が 4 分 30 秒 4 分 56 秒程度が列車待ち時間に対する 意識限界であることが分かった。

本研究より，人間の交通行動において時間の差に対す る意識の限界がある可能性が確かめられた．このことは， 各種交通需要予測においても，ある程度人間の意識限界 を考慮することが求められることを意味しているといえ る.

\section{(2)今後の課題}

本研究では定常的な選択状況を分析対象としたため, 時間の差異についても静的な分析に留まっている. した がって，例えば，サービス水準の改善程度が微少な場合 におけるプロジェクトについて，その意識限界を検証す るためには，動的な微少変化に対する人間の意識限界を 分析寸る必要があるであろう。

また，本研究においては時刻選択行動の分析に当たり， MNL モデルを用いているが，本来連続量である時刻を 離散化すると選択肢間の相関や偏りが生じる可能性が指 摘されている. その意味で, 本研究では操作の簡易さを 考慮し MNL モデルを用いたが，今後はこのような選択 肢間の誤差相関を明示的に考慮できる時刻選択モデルを 用いて分析を行う必要があると考えられる.

これらについては, 今後の課題としたい. 
付録 記号表

(1)時刻に関する記号 (単位はすべて秒)

\begin{tabular}{|c|c|}
\hline 記号 & 意味 \\
\hline$i$ & 自宅出発時刻 \\
\hline$j$ & 最寄騃到着時刻 \\
\hline$T_{o n}$ & 就業地到着時刻 \\
\hline$T_{d j n}$ & 最寄駅で時刻 $j_{n}$ より後に最初に到着する列車の発車時刻 \\
\hline$T_{d d n}$ & 最終不遅刻列車の発車時刻 \\
\hline$T_{d p n}$ & 乗車希望列車の発車時刻 \\
\hline$\widetilde{j}_{n}$ & 最寄騃到着時刻の観測值 \\
\hline$\hat{i}_{n}$ & 推定自宅出発時刻 \\
\hline
\end{tabular}

(2)時間に関する記号（単位はすべて秒)

\begin{tabular}{|c|l|}
\hline 記号 & \multicolumn{1}{|c|}{ 意味 } \\
\hline$t_{w j n}$ & 列車待ち時間 \\
\hline$t_{d d j n}$ & 最終不遅刻列車スケジュール遅延 \\
\hline$t_{e d j n}$ & 最終不遅刻列車スケジュール早着 \\
\hline$t_{d p j n}$ & 乗車希望列車スケジュール遅延 \\
\hline$t_{e p j n}$ & 乗車希望列車スケジュール早着 \\
\hline $\bar{t}_{w j n}$ & 期待列車待ち時間 \\
\hline $\bar{t}_{d d j n}$ & 最終不遅刻列車期待スケジュール遅延 \\
\hline $\bar{t}_{e d j n}$ & 最終不遅刻列車期待スケジュール早着 \\
\hline $\bar{t}_{d p j n}$ & 乗車希望列車期待スケジュール遅延 \\
\hline $\bar{t}_{e p j n}$ & 乗車希望列車期待スケジュール早着 \\
\hline$t_{a j j n}$ & アクセス所要時間 \\
\hline$t_{w j n}$ & 列車待ち時間 \\
\hline$t_{r j n}$ & 列車乗車時間 (乗換時間含む) \\
\hline$t_{e j n}$ & イグレス所要時間 \\
\hline $\bar{t}_{a n}$ & 平均的なアクセス所要時間 \\
\hline$t_{a n n a x}$ & アクセス所要時間の最大值 \\
\hline$t_{a n N n}$ & アクセス所要時間の最小值 \\
\hline
\end{tabular}

\section{【参考文献】}

1) Krishnan, K.S. : Incorporating thresholds of indifference in probabilistic choice models, Management Science, Vol.23, No.11, pp.1224-1233, 1977.

2) 加藤浩徳，家田仁，小野田惠一 : 都市鉄道の経路選択行動に おける最小知覚差の計測, 土木計画学研究・講演集, No.26,

(CD-ROM)， 2002.

3）小野耕司, 祖田圭介 : 意識データによる鉄道所要時間短縮の 効果評価，鉄道総研報告，Vol.14，No.12，pp.37-40，2000

4) 家田仁，後藤貞二，松本嘉司，島崎敏一 : 通勤者における消 費時間弁別䦨の確率的評価，土木学会論文集，第383号/IV-7, pp.73-81, 1987.

5) 大山正, 今井省吾, 和気典二編 : 新編 感覚・心理学ハンドブ ック, 誠信書房, pp.19-21, 1994.

6) Vickrey, W.S. : Congestion theory and transport investment, American Economic Review, Vol.59, No.2, pp.251-260, 1969.

7) Hall, R.W. : Travel outcome and performance: the effect of uncertainty on accessibility, Transportation Research-B, Vol.17B, No.4, pp.275-290, 1983.

8）松本昌二，白水義晴 : 通勤交通における旅行時間の変動と到 着目標時刻の設定, 土木計画学研究・講演集, No.8, pp.207214, 1986.

9）内田敬，飯田恭敬，松下晃 : 通勤ドライバーの出発時刻决定 行動の実証分析, 土木計画学研究・論文集, No.10, pp.39-46, 1992

10)松井寛, 藤田素弘 : フレックスタイム下における通勤時刻選 択行動とその効果分析, 土木学会論文集, No.470/IV-20, pp.67-76, 1993

11)家田仁，竹村宗能，岡村敏之，今泉航太 : 労動時間の違いを 考虑した鉄道通勤者の出社行動の分析, 土木計画学研究・ 講演集, No.20(1), pp.429-432, 1997.

12) Small, K. A.: The Scheduling of Consumer Activities: Work Trips, The American Economic Review, Vol.72, No.3, pp.467-479, 1982

13) de Palma, A. and Fontan, C.: Departure time choice and heterogeneity of commuters, Proceedings of $\mathrm{g}^{\text {th }}$ World Conference on Transport Research.

14) Henderson, C. and Plank, E.: The flexibility of departure times for work trips, Transportation Research A, Vol.18A, No.1, pp.25-36, 1984

15）藤原章正，神田佑亮，杉惠頼寧，岡村敏之 : 時刻選択モデ ルの選択肢区分が選択肢間の類似性及び不均一性に及ぼす 影響, 土木計画学研究・論文集, No.17, pp.599-604, 2000

\section{MNLに基づく出発時刻選択行動モデルを用いた通勤鉄道利用者の列車待ち時間に対する意識限界に関する実証的分析*}

加藤浩徳"，家田仁"-，小野田惠一

本論文では，出発時刻選択モデルを用いて，通勤者の交通行動を分析し，その結果から，時間の差に対する意識限界を推定した. 出 発時刻選択モデルを構筑する上で，通勤者の選択行動に影響を与える説明変数を検討し，列車待ち時間・乗車希望列車スケジュール早 着・同スケジュール遅延・最終不遅刻列車スケジュール早着の組み合わせが適切であることを示したそそのモデルを用いて，鉄道利用 者の通勤行動を分析した結果，時間の差に対する意喑限界は平均運行時隔にして約 4 分 30 秒 44 分56秒であることが分かった。

\footnotetext{
Valuation of Perception Threshold of Waiting Time at Railway Station by Departure Time Choice Model Based on the MNL model ${ }^{* *}$

By Hironori KATO"*, Hitoshi IEDA" ${ }^{-*}$, Keiichi ONODA

This paper aims to valuate the perception threshold of waiting time of rail-use-commuters. The departure time choice model based on the MNL model is used to formulate the traveler's behavior when they commute from home to their work places via railway stations. The arriving time of commuters at the railway station is observed is under an assumption that they minimize the waiting time by taking accounts of their departure time from home and the operating schedule of railway at the station. As a result of statistical analysis, the expected perception threshold of waiting time is around 4.5 to $5 \mathrm{~min}$.
} 